DOI: https://doi.org/10.18485/bells.2016.8.6

UDC: 811.111:371.275

\author{
Ana Tomović* \\ Tamara Aralica** \\ Katarina Rasulić \\ University of Belgrade \\ Faculty of Philology \\ Serbia
}

\title{
MIND THE GAP! THREE YEARS DOWN THE LINE FROM THE ENTRANCE EXAM AT THE ENGLISH DEPARTMENT, FACULTY OF PHILOLOGY, BELGRADE
}

\begin{abstract}
This paper examines the nature and degree of correlation between the candidates' entrance exam results and their respective results in the Contemporary English G5 exam in the third year of undergraduate studies at the English Department, Faculty of Philology, University of Belgrade. It assesses the predictive validity of the entrance exam as a selection tool and highlights the need of a more balanced development of language competences and skills in EFL university studies. The analysis comprises the scores achieved by 218 students from two generations (entrance exam 2011 and 2012, Contemporary G5 exam 2014 and 2015, respectively) in the following exam components: English in use (grammar and vocabulary), reading comprehension, listening comprehension and writing. The findings indicate satisfactory overall predictive validity of the entrance exam, whereby, more specifically, they reveal a high degree of correlation between the writing and listening comprehension scores but a considerable discrepancy between the English in use (grammar and vocabulary) and reading comprehension scores
\end{abstract}

\footnotetext{
E-mail address: anatom0707@gmail.com

** E-mail address: vtaralica@gmail.com

${ }^{* * *}$ E-mail address: k.rasulic@fil.bg.ac.rs
} 
achieved in the entrance exam (B2+ level) and in the third year Contemporary English G5 exam (C2.1 level). The findings should ultimately serve as a basis for further qualitative research and improvement of the interaction between teaching, learning and assessment across different levels of EFL university studies.

Key words: entrance exam (B2+), Contemporary English G5 exam (C2.1), English in use, reading comprehension, listening comprehension, writing, predictive validity

\section{Introduction}

Using a specifically designed entrance exam as a selection tool is one way of ensuring that universities get the best candidates in a particular field of study, who will in return make the most of their education and later successfully apply that knowledge in their professions. Among other things, this is also a way in which these tertiary institutions establish and maintain their reputation. In the Serbian education system, disciplinespecific entrance exams have traditionally been used as a selection tool at state universities. They are generally administered for two reasons: (i) to select fewer candidates when the number of applicants exceeds the limit set by a faculty, and (ii) to choose the most prospective candidates (Fajgelj and Knebl 2004).

This is also the case with the English Department at the Faculty of Philology, University of Belgrade, where the current entrance exam (for candidates who apply for the English language, literature and culture curriculum, on average twice more than the set limit) assesses Grammar and Vocabulary, Reading Comprehension, Listening Comprehension and Writing at the B2+ CEFR level (cf. Council of Europe 2001), with the minimum requirement entry score being $60 \%$.

However, within the ongoing process of education reforms in Serbia, by the year 2020, discipline-specific university entrance exams are to be replaced by a standardized national matriculation exam, which should serve as the general admission test for different fields of university studies (with the exception of university programmes requiring special skills such as drama, music, art or sports, whereby the status of foreign language skills as special skills is unclear). ${ }^{1}$ The development of the upcoming

1 This change has been planned since 2012 in the official Serbian Government Education Development Strategy 2020 (Službeni glasnik Republike Srbije 107/12, 2012) and the 
matriculation exam is still in progress, but it should roughly correspond to the A-level exams in the UK, or the SAT college admission test in the US. ${ }^{2}$ Obviously, deciding on the most appropriate testing format which would be effective as an admission tool for a wide variety of university programmes is far from an easy task. All the more so from the point of view of foreign language university programmes, in particular EFL university programmes, which require a certain level of foreign language proficiency already at the entry. In this regard, the importance of a well-designed test capable of determining with a great degree of accuracy the right profile of a candidate cannot be overemphasized.

Exploring the relationship between students' success in the admission test and their performance in the first and later years of study at different levels of tertiary education is an important area of research (cf. Zwick 2002, 2006, 2007, Kuncel, Hezlett and Ones 2001). One of the underlying ideas of this kind of research is to keep the admission procedures in sync with university requirements and the objectives and outcomes of tertiary education. The awareness of the quality of entrance exams or other selection tools and their correspondence with later stages of study is one way of ensuring that students really benefit from the education they get and develop to their full potential.

With this in mind, in this paper we address the issue of the predictive validity of the discipline-specific entrance exam at the English Department, Faculty of Philology, University of Belgrade. In particular, we examine the nature and degree of correlation between the candidates' entrance exam results (B2+ CEFR level) and their respective results in the Contemporary English G5 exam (C2.1 CEFR level) in the third year of undergraduate studies, on the basis of a quantitative analysis of a sample of results

interim 2015 Action Plan for its implementation (http://www.mpn.gov.rs/wp-content/ uploads/2015/08/Akcioni_plan.pdf). In November 2016, the Serbian Education Minister publicly announced that the implementation of the matriculation exam replacing university entrance exams would start as of 2018 (http://www.b92.net/info/vesti/index. php?yyyy $=2016 \& \mathrm{~mm}=11 \& \mathrm{dd}=10 \&$ nav_category $=11 \&$ nav_id=1197925).

2 A-level exams are standardised tests in a number of subjects taught in high school, the scores of which are used as an admission tool by universities in the UK. The SAT is a standardised university admission test in the US, assessing a candidate's knowledge of critical reading, writing and mathematics. 
achieved by 218 students from two generations. ${ }^{3}$ Thereby, we focus on the following research questions:

(1) How do the candidates' entrance exam scores in the four pertinent components (Grammar and Vocabulary, Reading Comprehension, Listening Comprehension, Writing) relate to the scores in the analogous components of the third year Contemporary English G5 exam?

(2) What do the obtained results reveal about

(i) the predictive validity of the entrance exam under consideration,

(ii) the expected balanced development of EFL proficiency from $\mathrm{B} 2+$ to $\mathrm{C} 2$ level during the course of university studies under consideration, and

(iii) the challenges of the discipline-specific entrance exam under consideration being replaced by a general matriculation exam as envisaged in the current reform of university admission policy in Serbia?

The study is case specific, but it may have broader implications in the context of EFL university education. The paper is structured as follows: the data and analytical procedure are described in Section 2, the results are presented and discussed in Section 3, and general concluding remarks with implications for further research are provided in Section 4.

\section{Data and analysis}

The analysis is based on two datasets comprising the scores achieved by 218 students who passed the Contemporary English G5 exam in 2014 (119 students) and in 2015 (99 students). ${ }^{4}$ These two groups of students took their entrance exams in 2011 and 2012, respectively. We compared the

\footnotetext{
3 The label G5 in Contemporary English G5 stands for the core EFL course in the fifth term of undergraduate English studiesat the Faculty of Philology, University of Belgrade ("G" is short for the Serbian word glavni 'main', which refers to the category of core foreign language courses; at the English Department, this category comprises Contemporary English G1-G6 courses during the first three undergraduate years).

4 Included in the analysis are only the scores of the students who passed the exam; the pass rate in the Contemporary English G5 exam was 82.6\% in 2014 and $76.7 \%$ in 2015.
} 
results of the entrance exam components and their Contemporary English G5 exam counterparts specified in Table 1:

Table 1. The exam components included in the analysis ${ }^{5}$

\begin{tabular}{|c|c|}
\hline $\begin{array}{l}\text { Entrance exam components } \\
\text { (B2 }+ \text { level })\end{array}$ & $\begin{array}{l}\text { Contemporary English G5 exam } \\
\text { counterparts }^{1} \text { (C2.1 level) }\end{array}$ \\
\hline $\begin{array}{l}\text { Grammar and Vocabulary } \\
\text { (a twenty-item multiple choice } \\
\text { test, containing a cloze and a set of } \\
\text { isolatedsentences) }\end{array}$ & $\begin{array}{c}\text { English in Use } \\
\text { (a forty-item test of grammatical and lexical } \\
\text { knowledge with the following tasks: a gapped } \\
\text { text, word formation, transformations and } \\
\text { error correction) }\end{array}$ \\
\hline $\begin{array}{l}\text { Reading Comprehension } \\
\text { (two texts treating general topics, } \\
\text { each followed by five multiple choice } \\
\text { items) }\end{array}$ & $\begin{array}{l}\text { Reading Comprehension } \\
\text { (a twenty-item test consisting of three parts: } \\
\text { a text with multiple choice comprehension } \\
\text { questions, a gapped text and a lexical cloze) }\end{array}$ \\
\hline $\begin{array}{l}\text { Listening Comprehension } \\
\text { (two recordings treating general } \\
\text { topics, each followed by five multiple } \\
\text { choice items) }\end{array}$ & $\begin{array}{l}\text { Listening Comprehension } \\
\text { (two recordings, one with a multiple choice } \\
\text { task and the other with a three-way matching } \\
\text { task 'Who Says What', five items each) }\end{array}$ \\
\hline $\begin{array}{l}\text { Writing } \\
\text { (a guided task with detailed } \\
\text { instructions regarding the } \\
\text { background information about the } \\
\text { topic and the specific points which } \\
\text { need to be covered) }\end{array}$ & $\begin{array}{l}\text { Writing } \\
\text { (two in-class assignments; in the first one, } \\
\text { students interpret visual data (graphs, charts, } \\
\text { tables) and write about trends; in the second, } \\
\text { students develop a topic by integrating } \\
\text { ideas and arguments from a limited number } \\
\text { of sources, using techniques such as } \\
\text { paraphrasing, summarising and quoting) }\end{array}$ \\
\hline
\end{tabular}

The entrance exam combines achievement and aptitude testing features. The former are reflected especially in the Grammar and Vocabulary component, whose creation is strictly guided by the EFL curricular elements covered at previous levels of education. In order to help prospective students prepare

5 In addition to the components specified here, the Contemporary English G5 exam also contains the Speaking part, which the entrance exam lacks. The current format of the entrance exam was introduced in 2009, as a modification of its 2006 predecessor, which originally assessed oral production as well; unfortunately, the speaking component was abandoned after three years due to the complexity of entrance exam administration. 
for the exam, each year the Faculty of Philology publishes a collection of past papers (cf. Daničić and Ilić 2015). The Contemporary English G5 exam involves achievement-based summative assessment. It builds on the topic-based syllabus of the corresponding course (and its counterparts in the first two undergraduate years), designed to foster the integration of language skills (with special emphasis given to productive skills, i.e. writing and speaking), the enhancement of lexical, grammatical, phonetic/ prosodic, orthographic/orthoepic, discourse, pragmatic, interactive and sociolinguistic competences, and the development of accuracy, fluency and range in accordance with the targeted level of proficiency.

In the analysis of the two datasets, for the purpose of comparison and ease of reference, all entrance exam and Contemporary English G5 exam scores were converted to a 10-point scale. We compared individual student scores for each exam component, and calculated average scores and discrepancy values ( \pm in relation to the entrance exam) for each component, as shown in Tables 4 and 5 provided in the Appendix. In assessing the predictive validity of the entrance exam components, we used a three-level grading scale designed for the purpose of analysis (mean discrepancy <0.5: strong predictive validity; mean discrepancy 0.5-1.0: satisfactory predictive validity; mean discrepancy $>1.0$ : weak predictive validity).

\section{Results and discussion}

The results of the analysis of the two datasets concerning the average scores and discrepancy values for each exam component are summarised in Table $2: 6$

\footnotetext{
6 Abbreviations: G5=Contemporary English G5 Exam; EE=Entrance Exam; EinU=English in Use; $\mathrm{GV}=$ Grammar and Vocabulary; $\mathrm{RC}=$ Reading Comprehension; LC=Listening Comprehension; W=Writing; Avg.=Average Score; Discrep.=Discrepancy.
} 
Ana Tomović, Tamara Aralica, Katarina Rasulić: Mind the Gap!

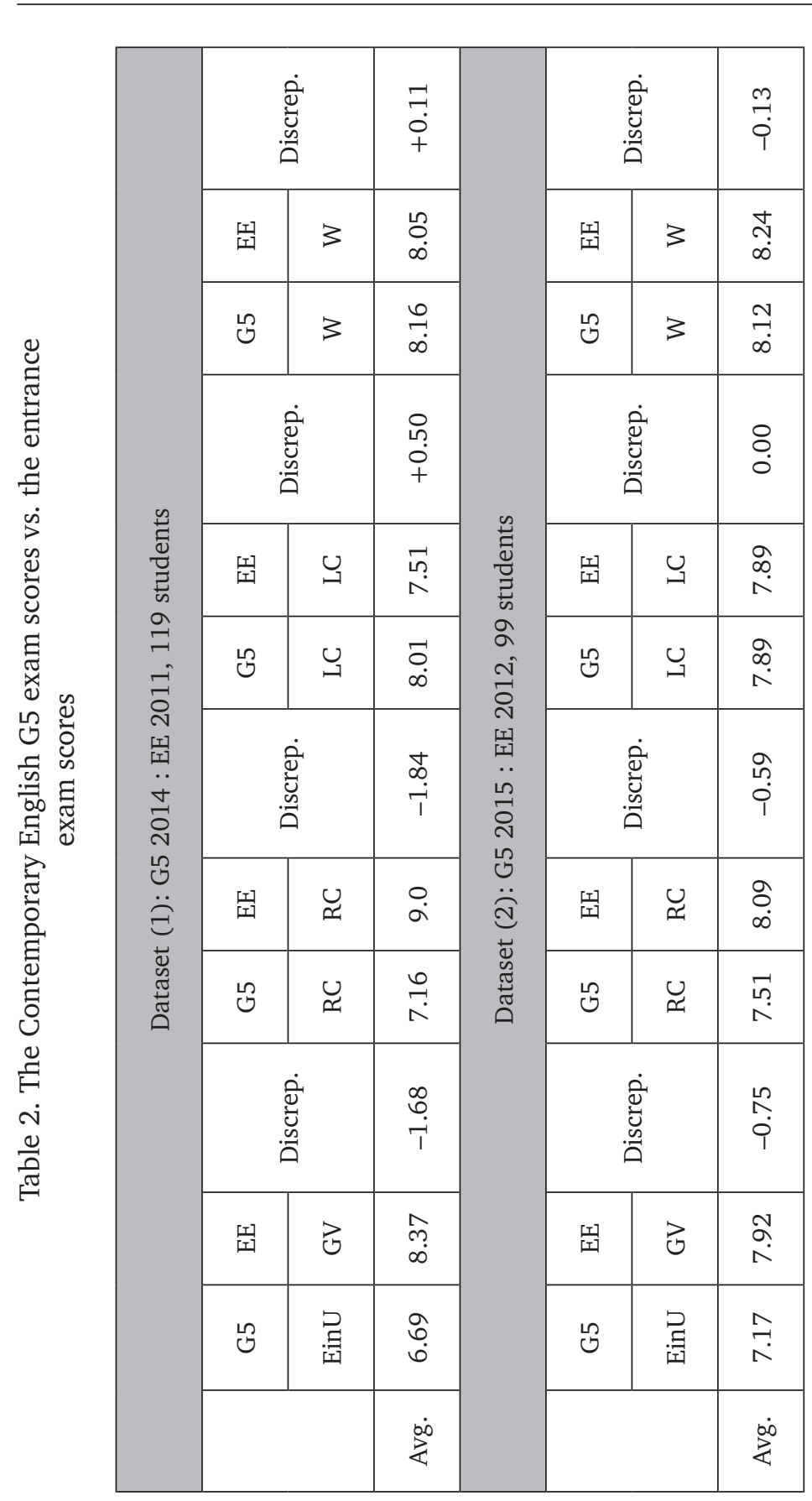


As can be discerned from this summary, in both datasets there is a significantly high degree of average score correlation in the writing and listening comprehension components, while the average scores in the English in use (grammar and vocabulary) and reading comprehension components manifest considerable discrepancies.

Specifically, the highest degree of average score correlation is found in the writing component, with a +0.11 discrepancy in the results in favour of the G5 exam for the 2011 generation, and a -0.13 discrepancy in favour of the entrance exam for the 2012 generation (the mean discrepancy value: -0.01 ). The correlation in the listening comprehension average scores is also significantly high, though less balanced in the two datasets: there is a +0.5 discrepancy in the results in favour of the G5 exam for the 2011 generation, while the results for the 2012 generation turn out to be identical in the entrance exam and the G5 exam (the mean discrepancy value: +0.25 ).

In the remaining two parts of the test - English in use (grammar and vocabulary) and reading comprehension - there is a noticeable decline in the G5 exam results compared to the entrance exam results, with the mean discrepancy value of over one full grade in both cases. Within the English in use (grammar and vocabulary) part of the test, there is a -1.68 discrepancy in favour of the entrance exam for the 2011 generation, and a -0.75 discrepancy in favour of the entrance exam for the 2012 generation (the mean discrepancy value: -1.215 ). As for the reading comprehension scores, there is a -1.84 discrepancy in favour of the entrance exam for the 2011 generation, and a -0.59 discrepancy in favour of the entrance exam for the 2012 generation (the mean discrepancy value: -1.215). Thereby it can be observed that, while the discrepancy in these two exam components is considerably higher in the dataset for the 2011 generation $(-1.68$ for EinU and -1.84 for RC) than for the 2012 generation $(-0.75$ for EinU and -0.59 for $\mathrm{RC}$ ), the overall decline pattern is discernible in both datasets. 
Ana Tomović, Tamara Aralica, Katarina Rasulić: Mind the Gap!

The pertinent discrepancy figures for the two datasets are summarised in Table 3:

Table 3. Average score discrepancies in the G5 and entrance exam components

\begin{tabular}{|c|c|c|c|}
\hline & G5 2014 : EE 2011 & G5 2015 : EE 2012 & Mean discrepancy value \\
\hline EinU (GV) & -1.68 & -0.75 & -1.215 \\
\hline RC & -1.84 & -0.59 & -1.215 \\
\hline LC & +0.5 & 0.00 & +0.25 \\
\hline Writing & +0.11 & -0.13 & -0.01 \\
\hline
\end{tabular}

These findings indicate that the entrance exam on the whole is a satisfactory predictor of future students' achievement in the core EFL courses at the English Department, Faculty of Philology, University of Belgrade: taking into account all four test segments under consideration, the overall mean discrepancy would be -0.5475 in favour of the entrance exam compared to the third year Contemporary English G5 exam. Thereby, the findings also reveal a substantial asymmetry in the degree of correlation between the entrance exam and the G5 exam scores in different exam components, which is particularly noteworthy in view of both assessment and teaching practices.

On the negative end, there is a considerable discrepancy between the entrance exam and the G5 exam in the English in use (grammar and vocabulary) and reading comprehension scores. Leaving aside the subjective factors (such as motivation and dedication or learning styles), this discrepancy could generally be attributed either (i) to the imbalanced difficulty of the pertinent tasks with regard to the required level (i.e. that the entrance exam tasks are too easy for the B2+ level or that the G5 exam tasks are too difficult for the C2.1 level) or (ii) to the imbalanced development of these competences and skills at more advanced levels of EFL university studies. Given that both the entrance exam and the G5 exam tests are carefully designed in accordance with the respective CEFR level requirements, and that our analysis includes the data pertaining to two generations of students, it is reasonable to exclude the first option as the major factor. Hence, we focus our attention to the second option and would like to highlight the need of a more balanced development of grammatical 
and lexical competences and reading skills in EFL university studies, with a view to the qualitative content underlying the quantitative data presented above. Namely, based on our yearlong experience in teaching third year undergraduate students at the English Department, Faculty of Philology, University of Belgrade, we can observe the following issues in particular:

(1) With regard to grammatical competence: students at C2.1-C2.2 level often keep struggling with some grammatical structures that should have been acquired at previous levels of study, even when they are comfortable with more complex structures suited to the targeted level of proficiency. Typical examples include the incorrect use of the Present Perfect in the transformation exercise or students' failure to even recognise the grammatical context requiring this structure (describing trends, pertinent time adverbials), or the incorrect use of mixed conditionals and inversion after negative adverbs, although these areas of grammar are dealt with in detail during the previous years of study.

(2) With regard to lexical competence: feeling comfortable with the already acquired advanced vocabulary, students at C2.1-C2.2 level tend to circumvent systematic vocabulary development suited to the targeted level of proficiency and show insufficient progress in enhancing lexical range and accuracy required for conveying finer shades of meaning. Typical examples include new idiomatic expressions, more complex intensifiers and other emphatic expressions, as well as required topic-based and more technical vocabulary (e.g. economy, global trends, the labour market). Generally, students' awareness of register and style still seems to be inadequate at this level, which is most visible in their discussing abstract topics or subjects which are not in their immediate sphere of interest.

(3) With regard to reading skills: apart from the backwash effect of the imbalanced vocabulary development described in (2), students generally read less and are insufficiently exposed to texts that require critical thinking.

On the positive end, there is a significantly high degree of correlation between the entrance exam and the G5 exam in the listening comprehension and writing scores. With regard to listening skills, this could likely be attributed to the ever increasing exposure of students to different audio materials 
in the media, especially the Internet - a factor that exceeds the scope of the present analysis. Thus we focus on the high degree of correlation in the writing scores, an issue that merits closer consideration for several reasons.

The writing segments of the two exams under investigation differ both in terms of the targeted level (B2+ and C2.1 respectively) and in terms of the nature of tasks, as described in Section 2. Nonetheless, they are comparable in terms of the structure of tasks and in terms of the standardised marking process. In both the entrance exam and the G5 exam, the writing tasks are guided and come with clearly defined instructions. The entrance exam task contains instructions which enable the candidates to use appropriate grammatical and lexical range, as well as strict guidelines on developing the topic. For the G5 exam tasks, students are provided with a great deal of lexical and grammatical task-specific input and are taught how to use appropriate strategies in elaborating on the topic. On both occasions every test is marked by two independent examiners and the scores are then averaged; passing scores range from 6 to 10, and if there is a 2 grade discrepancy, another examiner (core reader) is called upon to make the final decision. ${ }^{7}$ The marking process is also standardised through band descriptors for the respective levels (B2+ for the entrance exam and C2.1 for the G5 exam).Considering that the third year language instructors and examiners are not familiar with the students' writing achievements in the entrance exam and in the first two years of studies, it is safe to say that under the circumstances the grading is objective, unbiased and standardised.

As stated above, the analysis shows a remarkably high degree of correlation between the writing scores in the entrance exam and in the G5 exam (the mean discrepancy: -0.01). Such a high degree of correlation suggests that (1) writing tasks are a reliable indicator of students' actual grammatical and lexical competences (i.e. in the writing tasks students use the grammar and vocabulary that they feel confident about, as opposed to the English in Use exam component, which elicits grammar and vocabulary items that students are expected to have acquired at a given level), and (2) from the point of view of the predictive validity of the entrance exam, it

\footnotetext{
7 For more details on the development and application of this scoring procedure in the entrance exam at the English Department, Faculty of Philology, University of Belgrade, see Katz 2008.
} 
is the writing component that is the clearest indicator of future students' achievement.

These findings confirm the validity of the writing component as a selection tool in admission tests for EFL university studies (with a standardised marking process as a prerequisite). As emphasized by Zwick (2007: 32) with regard to higher education admission testing in general, "the proponents of aptitude tests and the advocates of classroom-based exams typically agree on a significant point: An assessment of writing ability should be included in admission tests ... [because] writing undeniably plays a key role in college-level work". Our analysis shows that this point also applies to EFL university entrance exams in particular.

Furthermore, if writing is such a valid indicator of students' future success in the core EFL courses, the question arises whether other components of the entrance exam are necessary at all, i.e. whether the writing component alone could be used as a reliable selection tool. Although this might contribute to the efficiency of administering the entrance exam and possibly yield a selection outcome similar to that of the current entrance exam format, we would like to stress the importance of comprehensive language assessment in admission tests for EFL university studies not only as a more precise indicator of the targeted proficiency level but also as a platform for adjusting and fine-tuning the syllabi of EFL university courses.

In particular, having in mind the manifest decline in students' performance in the English in use (grammar and vocabulary) and reading comprehension exam components, we would like to place emphasis on the need of paying more systematic attention to the explicit teaching and formative assessment of these aspects of EFL proficiency at the university level (hence the warning in the title of the paper). This especially concerns grammatical and lexical competence, commonly acknowledged as the necessary component in theoretical accounts of communicative competence (cf. Hymes 1972, Canale and Swain 1980, Savignon 1997[1983], Trbojević 2003), but often backgrounded in the practice of communicative language teaching. As long observed by Swan (1985b: 78): "Unfortunately, grammar has not become any easier to learn since the communicative revolution." In this regard, building on Gipps's (1994: 15-16) view of assessment "in dynamic interaction" with teaching and learning, we see the feedback on

\footnotetext{
8 For more details on the advantages and disadvantages of the communicative approach to language teaching, see e.g. Swan 1985a, 1985b, Bax 2003, Harmer 2003.
} 
Ana Tomović, Tamara Aralica, Katarina Rasulić: Mind the Gap!

the problematic issues arising in the C2.1 level summative assessment as instrumental in fostering a better vertical synchronization across the EFL university curriculum.

Finally, in view of the fact that the Serbian education system is about to replace the discipline-specific university entrance exams with a general matriculation exam (as described in the Introduction), the question arises whether such an exam would be an appropriate selection tool for EFL university programmes or whether it would be necessary to keep the discipline-specific entrance exam, treating foreign language skills as special skills. Based on the findings obtained in this study, we argue in favour of the second option, underlining that the effective selection of candidates for EFL university studies requires an admission tool specifically designed for this purpose.

\section{Concluding remarks}

On the basis of a quantitative analysis comparing the results achieved by 218 students from two generations in the Contemporary English G5 exam (C2.1 level) and the entrance exam (B2+ level) at the English Department, Faculty of Philology, University of Belgrade, we have established the following: (1) the highest degree of correlation occurs in the writing scores, which indicates that the writing component of the entrance exam has the strongest predictive validity; (2) there is a manifest decline in the English in use (grammar and vocabulary) and reading comprehension scores, which indicates the need of paying more systematic attention to the explicit teaching and formative assessment of these aspects of EFL proficiency at the university level; (3) from the perspective of EFL competences and skills, the discipline-specific entrance exam has advantages over a general matriculation exam as a more appropriate selection tool for EFL university programmes. These findings, as presented and discussed in Section 4, could provide a fruitful basis for further qualitative research (both longitudinal and cross-sectional) with a view to enhancing the interaction between teaching, learning and assessment across different levels of EFL university studies. 


\section{References}

Bax, S. (2003). The end of CLT: A context approach to language teaching. English Language Teaching Journal, 57, 278-287.

Canale, M. and M. Swain (1980). Theoretical bases of communicative approaches to second language teaching and testing. Applied Linguistics, $1,1-47$.

Council of Europe (2001). Common European Framework of Reference for Languages: Learning, Teaching, Assessment. Cambridge: Cambridge University Press.

Daničić, M. and N. Ilić (2015). Zbirka testova sa prijemnih ispita iz engleskog jezika (za profil Engleski jezik i književnost). Beograd: Filološki fakultet.

Fajgelj, S. and J. Knebl (2004). Da li se može eliminisati pogađanje na prijemnim ispitima? Psihologija, 37 (2), 195-207.

Gipps, C.V. (1994). Beyond Testing. Towards a Theory of Educational Assessment. London: The Falmer Press.

Harmer, J. (2003). Popular culture, methods, and context. English Language Teaching Journal, 57, 288-294.

Hymes, D.H. (1972). On communicative competence. In: Pride, J.B. and J. Holmes (eds.), Sociolinguistics. Selected Readings, Harmondsworth: Penguin, 269-293.

Katz, A. (2008). Changing the culture of assessment: Redefining proficiency. In: Rasulić, K. and I. Trbojević (eds.), ELLSSAC Proceedings (International Conference English Language and Literature Studies: Structures across Cultures), Belgrade: Faculty of Philology, 615-629.

Kuncel, N.R., S.A Hezlett and D.S. Ones (2001). A comprehensive metaanalysis of the predictive validity of Graduate Record Examinations: Implications for graduate student selection and performance. Psychological Bulletin, 127/1, 162-181.

Savignon, S. (1997 [1983]). Communicative Competence: Theory and Classroom Practice: Texts and Contexts in Second Language Learning, $2^{\text {nd }}$ edition. New York: McGraw-Hill.

Swan, M. (1985a). A critical look at the communicative approach (1). English Language Teaching Journal, 39(1), 1-12.

Swan, M. (1985b). A critical look at the communicative approach (2). English Language Teaching Journal, 39(2), 76-87. 
Ana Tomović, Tamara Aralica, Katarina Rasulić: Mind the Gap!

Trbojević Milošević, I. (2003). Komunikativna kompetencija između sociolingvistike i primenjene lingvistike. U: Klikovac, D. and K. Rasulić (ur.), Jezik, društvo, saznanje: profesoru Ranku Bugarskom od njegovih studenata, Beograd: Filološki fakultet, 257-271.

Zwick, R. (2002). Fair Game? The Use of Standardized Admissions Tests in Higher Education. New York: RoutledgeFalmer.

Zwick, R. (2006). Higher education admissions testing. In: Brennan, R.L. (ed.), Educational Measurement (4th edition), Westport, CT: American Council on Education/Praeger, 647-679.

Zwick, R. (2007). College Admission Testing. National Association for College Admission Councelling Report, February 2007, Arlington, VA: NACAC.

\section{Appendix}

The tables below provide individual student scores (converted to a 10-point scale) for each Contemporary English G5 and entrance exam component, as well as the pertinent average scores and discrepancy values in the two datasets. 


\begin{tabular}{|c|c|c|c|c|c|c|c|c|c|c|c|c|c|c|c|c|c|c|c|c|c|}
\hline 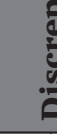 & 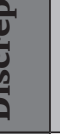 & $\overrightarrow{0}$ & $\stackrel{r}{\longrightarrow}$ & $\stackrel{\infty}{-}$ & $\vec{i}$ & $\stackrel{a}{0}$ & $\begin{array}{l}1 \\
1 \\
0 \\
0 \\
1\end{array}$ & $\stackrel{2}{2}$. & $\stackrel{\sim}{-}$ & ت. & $\begin{array}{l}\infty \\
0 \\
0 \\
1\end{array}$ & 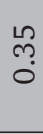 & $\begin{array}{l}\stackrel{1}{+} \\
\dot{0} \\
i\end{array}$ & $\begin{array}{l}n \\
0 \\
0 \\
0\end{array}$ & $\mid \begin{array}{c}2 \\
\hat{0} \\
0\end{array}$ & $\stackrel{0}{0}$ & $\begin{array}{l}n \\
0 \\
0 \\
1\end{array}$ & $\begin{array}{l}L \\
\infty \\
0 \\
0\end{array}$ & $\stackrel{+}{\stackrel{+}{r}}$ & $\begin{array}{l}\stackrel{2}{\hat{2}} \\
\stackrel{i}{i}\end{array}$ & 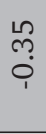 \\
\hline ㄸ⿱㇒木几ा & 3 & $\infty$ & $\infty$ & صُ & $\stackrel{\llcorner}{\Gamma}$ & $\infty$ & $\stackrel{0}{-1}$ & $\stackrel{\text { Ln }}{a}$ & 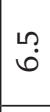 & $\infty$ & In & $\infty$ & $a$ & $\infty$ & $\curvearrowright$ & $\begin{array}{l}10 \\
\infty\end{array}$ & $\curvearrowright$ & $\infty$ & $\infty$ & $\stackrel{\llcorner}{a}$ & $\infty$ \\
\hline น & 3 & $\vec{\infty}$ & $\vec{a}$ & $\begin{array}{l}m \\
\infty \\
\infty\end{array}$ & $\left|\begin{array}{l}\infty \\
i n \\
i n\end{array}\right|$ & $\stackrel{a}{\infty}$ & 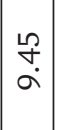 & $\begin{array}{l}\stackrel{2}{\mu} \\
\alpha\end{array}$ & $\stackrel{\curvearrowright}{\curvearrowright}$ & $\stackrel{a}{\Lambda}$ & $\widehat{\infty}$ & 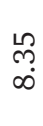 & 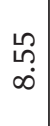 & $\begin{array}{l}n \\
0 \\
\end{array}$ & $\mid \begin{array}{l}\stackrel{2}{2} \\
\stackrel{2}{\sim}\end{array}$ & $\ddot{a}$ & 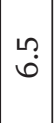 & $\begin{array}{l}n \\
\infty \\
\infty \\
\infty\end{array}$ & $\begin{array}{l}0 \\
\dot{0}\end{array}$ & 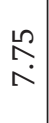 & 号 \\
\hline$\frac{\delta}{E}$ & 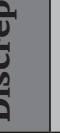 & $\sim$ & 0 & $\sim$ & -1 & N & 7 & $r$ & 0 & - & $-r$ & $N$ & 0 & 0 & $\neg$ & & N & $\neg$ & $m$ & 广 & 0 \\
\hline 됲 & u⿶ & 0 & $\infty$ & 0 & $\infty$ & $\Lambda$ & $a$ & $\infty$ & $\infty$ & $\infty$ & $\Lambda$ & $\Lambda$ & $a$ & $\infty$ & $\wedge$ & $a$ & in & 음 & L & $\stackrel{\circ}{\rightarrow}$ & $\wedge$ \\
\hline ᄂ & U্⿶ & $\infty$ & $\infty$ & $\infty$ & $a$ & $a$ & $\infty$ & $a$ & $\infty$ & $a$ & $\infty$ & $a$ & $a$ & $\infty$ & 0 & $\Lambda$ & $\curvearrowright$ & $a$ & $\infty$ & 0 & $\wedge$ \\
\hline & 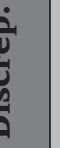 & 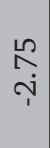 & $\begin{array}{l}10 \\
\uparrow \\
\uparrow\end{array}$ & $m$ & $\begin{array}{l}\text { Ln } \\
\hat{0} \\
1\end{array}$ & זִ ְִ & 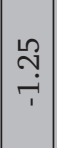 & $\begin{array}{l}\stackrel{1}{N} \\
\text { p̦ } \\
\uparrow\end{array}$ & 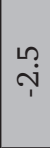 & & $\begin{array}{l}\stackrel{\sim}{N} \\
\stackrel{N}{N} \\
\uparrow\end{array}$ & $\vec{T}$ & \begin{tabular}{|l|}
1 \\
0 \\
0 \\
1
\end{tabular} & $\begin{array}{l}\stackrel{2}{N} \\
\dot{T}\end{array}$ & 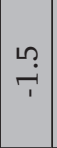 & 象 & $\neg$ & $\uparrow$ & $\begin{array}{l}\stackrel{1}{n} \\
\text { ஸे } \\
\text { r }\end{array}$ & 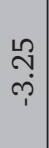 & q \\
\hline 됲 & U્ય & $\infty$ & $\underset{-1}{-1}$ & $a$ & 0 & $\infty$ & 욱 & $\stackrel{-}{-1}$ & $a$ & $\infty$ & $\infty$ & $a$ & $a$ & 음 & $\infty$ & $a$ & $a$ & $\stackrel{\circ}{-}$ & $a$ & $\stackrel{ }{-}$ & $\stackrel{ }{\rightarrow}$ \\
\hline นึ & U & $\begin{array}{l}\stackrel{1}{N} \\
\text { ம் }\end{array}$ & 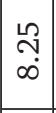 & 0 & $\begin{array}{c}\text { L } \\
\text { in } \\
\text { in }\end{array}$ & นึ & 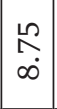 & $\begin{array}{l}\stackrel{n}{\hat{\sigma}} \\
.\end{array}$ & นُ & นִ & 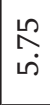 & $\infty$ & \begin{tabular}{|l|l|}
10 \\
$\infty$ \\
\end{tabular} & $\begin{array}{l}\Omega \\
\hat{\Lambda} \\
i\end{array}$ & \begin{tabular}{|l|l|}
$n$ \\
0 \\
0
\end{tabular} & $\stackrel{?}{a}$ & $\infty$ & $\infty$ & 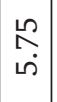 & $\begin{array}{l}\stackrel{2}{\hat{\sigma}} \\
\dot{0}\end{array}$ & $\wedge$ \\
\hline & $\frac{\dot{v i t}}{\dot{v}}$ & 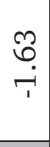 & $\nabla_{1}$ & $\begin{array}{l}m \\
\sim \\
-\end{array}$ & 0 & $\begin{array}{l}\text { శુ } \\
\stackrel{\gamma}{1}\end{array}$ & 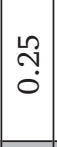 & $\begin{array}{l}n \\
\hat{0} \\
\end{array}$ & $\begin{array}{c}\infty \\
\stackrel{m}{+}\end{array}$ & $\begin{array}{l}m \\
\stackrel{m}{\longrightarrow}\end{array}$ & 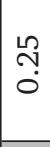 & ד & $\begin{array}{l}\stackrel{1}{n} \\
\tilde{r} \\
\end{array}$ & $\begin{array}{l}n \\
\hat{N} \\
i \\
i\end{array}$ & $m$ & $\begin{array}{l}\infty \\
\infty \\
\\
\\
\end{array}$ & 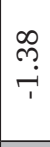 & $\begin{array}{l}\infty \\
\infty \\
0 \\
0\end{array}$ & $\begin{array}{l}\stackrel{1}{n} \\
\stackrel{0}{0} \\
i\end{array}$ & $\begin{array}{l}\stackrel{20}{\Upsilon} \\
\stackrel{+}{+}\end{array}$ & $\begin{array}{l}\tilde{O} \\
\stackrel{1}{i} \\
\text {. }\end{array}$ \\
\hline 四 & $\overrightarrow{0}$ & $\infty$ & $\begin{array}{l}10 \\
\infty \\
\infty\end{array}$ & $\begin{array}{l}10 \\
\infty\end{array}$ & $\begin{array}{l}\text { Ln } \\
\text { 10 }\end{array}$ & $\begin{array}{l}\llcorner 0 \\
\infty\end{array}$ & $\infty$ & $\stackrel{ }{\circ}$ & $\stackrel{L}{\alpha}$ & $\begin{array}{l}\llcorner 0 \\
\infty\end{array}$ & $\wedge$ & $\infty$ & $\underset{\sim}{\stackrel{-}{1}}$ & $\begin{array}{l}10 \\
\infty\end{array}$ & $\left|\begin{array}{l}10 \\
\infty\end{array}\right|$ & $\stackrel{L}{\alpha}$ & $\stackrel{\stackrel{n}{R}}{\Lambda}$ & \begin{tabular}{|l|}
10 \\
$\infty$ \\
$\infty$
\end{tabular} & $\stackrel{\llcorner ?}{\sim}$ & $\stackrel{ }{\circ}$ & $\infty$ \\
\hline ᄂ & 总 & ஸ़ & $\stackrel{2}{\sim}$ & مִ & 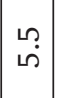 & $\begin{array}{l}\hat{\infty} \\
\text { in }\end{array}$ & $\begin{array}{l}\stackrel{1}{0} \\
\infty \\
\infty\end{array}$ & $\begin{array}{l}\stackrel{n}{n} \\
\text { a }\end{array}$ & $\underset{\sim}{\stackrel{F}{\sim}}$ & $\stackrel{\widehat{m}}{\wedge}$ & $\stackrel{\stackrel{\sim}{n}}{\stackrel{n}{N}}$ & $\Lambda$ & $\begin{array}{l}\stackrel{2}{\hat{\sigma}} \\
\hat{0}\end{array}$ & 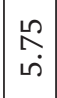 & $\left|\begin{array}{l}n \\
\text { மூ }\end{array}\right|$ & ִָ & $\stackrel{\sim}{\underset{0}{\sigma}}$ & $\begin{array}{l}\tilde{N} \\
\end{array}$ & $\stackrel{\stackrel{\llcorner}{N}}{\stackrel{N}{N}}$ & $\begin{array}{l}\stackrel{L}{N} \\
\stackrel{n}{n}\end{array}$ & 命 \\
\hline & & - & $N$ & $m$ & $\nabla$ & Ln & 0 & $\Lambda$ & $\infty$ & $a$ & 윽 & $F$ & $\stackrel{\sim}{\sim}$ & $\stackrel{m}{\rightarrow}$ & $\underset{\sim}{\forall}$ & 10 & $\stackrel{0}{\sim}$ & $\approx$ & 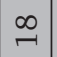 & $\stackrel{a}{\neg}$ & ㅇ \\
\hline
\end{tabular}




\begin{tabular}{|c|c|c|c|c|c|c|c|c|c|c|c|c|c|c|c|c|c|c|c|c|c|}
\hline \multicolumn{2}{|c|}{ 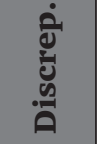 } & $\begin{array}{l}10 \\
\stackrel{1}{0} \\
0\end{array}$ & 뭄. & $\stackrel{\text { ஜn }}{\circ}$ & $\begin{array}{l}\text { ก } \\
\text { Oे }\end{array}$ & & 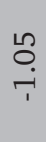 & $\stackrel{\text { மூ }}{\circ}$ & $\begin{array}{l}\stackrel{2}{0} \\
\stackrel{0}{i}\end{array}$ & 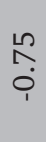 & 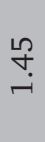 & $\hat{i}$ & $\begin{array}{l}\stackrel{\text { }}{m} \\
0\end{array}$ & 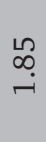 & 뭉. & ơ & $\begin{array}{l}\text { Ln } \\
0 \\
0\end{array}$ & $\stackrel{\overbrace{}}{\digamma}$ & $\stackrel{\text { Po }}{\text { - }}$ & ־. & @̊ \\
\hline 되도 & 3 & $\stackrel{n}{\Lambda}$ & $\Lambda$ & $\Lambda$ & ᄂ? & $\Lambda$ & $\stackrel{ }{-1}$ & $\infty$ & $\begin{array}{l}\sim \\
\infty\end{array}$ & $\stackrel{ }{-1}$ & $\Lambda$ & $a$ & $\Lambda$ & ㄴ? & $a$ & $\begin{array}{l}1 ? \\
\infty\end{array}$ & $a$ & $\stackrel{ }{\circ}$ & $\infty$ & $a$ & $\infty$ \\
\hline L & 3 & $\stackrel{\text { }}{n}$ & $\stackrel{20}{\stackrel{1}{ }}$ & 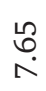 & ํํ & $\underset{\infty}{\infty}$ & $\begin{array}{l}\llcorner \\
\alpha \\
\infty\end{array}$ & $\begin{array}{l}\qquad 0 \\
\infty \\
\infty\end{array}$ & ஸ़ & $\stackrel{\text { ก๊ }}{a}$ & $\begin{array}{l}\stackrel{\operatorname{Ln}}{+} \\
\infty\end{array}$ & $\begin{array}{l}\infty \\
\infty\end{array}$ & $\stackrel{\stackrel{\llcorner}{m}}{\stackrel{n}{n}}$ & $\begin{array}{l}\stackrel{\text { ñ }}{\text { å }}\end{array}$ & $\hat{\infty}^{\circ}$ & $\stackrel{\infty}{\wedge}$ & 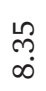 & $\infty_{\infty}^{\infty}$ & $\begin{array}{l}\stackrel{\operatorname{p}}{+} \\
\sigma\end{array}$ & $\stackrel{\Omega}{\wedge}$ & $\stackrel{r}{r}$ \\
\hline \multicolumn{2}{|c|}{ 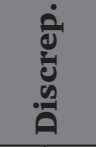 } & ㄱ & $r_{1}$ & 0 & ㄱ & $N$ & 0 & $m$ & $\sim$ & $m$ & 0 & ฯ & $\neg$ & 0 & -1 & $\neg$ & 0 & $m$ & $\neg$ & ז & -1 \\
\hline 똑 & U & $\infty$ & $\infty$ & $\infty$ & $a$ & $\infty$ & $\stackrel{0}{\rightarrow-1}$ & 0 & 0 & $\Lambda$ & $a$ & 음 & $\Lambda$ & $\infty$ & $\Lambda$ & $\Lambda$ & $\Lambda$ & $\Lambda$ & $\infty$ & $\infty$ & $\infty$ \\
\hline L & U & $\Lambda$ & $\Lambda$ & $\infty$ & $\infty$ & $\stackrel{ }{\circ}$ & $\stackrel{ }{\circ}$ & $a$ & $\infty$ & $\stackrel{0}{-1}$ & $a$ & $\infty$ & $\infty$ & $\infty$ & $\infty$ & $\infty$ & $\Lambda$ & $\stackrel{0}{\circ}$ & $a$ & 0 & $a$ \\
\hline \multicolumn{2}{|c|}{$\begin{array}{l}\dot{0} \\
\text { ঠ் } \\
\dot{0} \\
\ddot{0}\end{array}$} & $\begin{array}{l}\stackrel{1}{N} \\
\text { ஸे }\end{array}$ & $\stackrel{\stackrel{\Perp}{\curvearrowright}}{\underset{\sim}{\rightleftharpoons}}$ & $\begin{array}{l}\text { กิ } \\
\text { pr }\end{array}$ & $\underset{1}{T}$ & 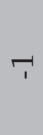 & $\stackrel{\text { L? }}{0}$ & $\begin{array}{l}\text { ஸे } \\
\text { +े }\end{array}$ & $\neg$ & $\stackrel{\text { ஸn }}{\text { ก }}$ & 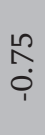 & $\stackrel{\text { In }}{\stackrel{1}{0}}$ & $\begin{array}{l}\text { ஸे } \\
\text { pr }\end{array}$ & 广 & भृ? & $\underset{1}{\Upsilon}$ & r & $\underset{1}{\Upsilon}$ & ஸึ & $\stackrel{10}{\stackrel{1}{\leftarrow}}$ & 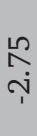 \\
\hline 되되 & $\underset{\approx}{U}$ & $a$ & $\infty$ & $\stackrel{\circ}{\circ}$ & $a$ & $\stackrel{ }{\circ}$ & $a$ & $\stackrel{0}{-1}$ & $a$ & $\infty$ & $a$ & $a$ & $\stackrel{0}{-1}$ & $\stackrel{0}{\rightarrow-1}$ & $\stackrel{ }{-}$ & $\stackrel{0}{-1}$ & $\infty$ & $\stackrel{\circ}{\circ}$ & $\stackrel{0}{\rightarrow-1}$ & $\stackrel{\circ}{\circ}$ & $\stackrel{ }{\circ}$ \\
\hline ᄂ & U & 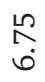 & ஸึ & 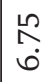 & $\Lambda$ & $a$ & เก & 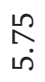 & $\infty$ & $\stackrel{\text { ஸ̊ }}{\text { å }}$ & $\begin{array}{l}\stackrel{\text { ஸִ }}{\infty} \\
\text { }\end{array}$ & $\begin{array}{l}\text { ヘึ } \\
\text { å }\end{array}$ & $\stackrel{10}{\stackrel{10}{\sigma}}$ & 0 & ᄂ? & $\infty$ & $\Lambda$ & $\infty$ & 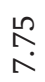 & $\begin{array}{l}\stackrel{1}{n} \\
\text { in }\end{array}$ & 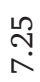 \\
\hline \multicolumn{2}{|c|}{ हैं } & חִ זִ & $\hat{n}$ & זִ & $\begin{array}{l}\text { రి } \\
\text { } \\
1\end{array}$ & חִָ & $\stackrel{\text { L? }}{0}$ & 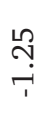 & 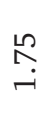 & $\begin{array}{l}\text { mo } \\
\dot{0}\end{array}$ & 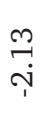 & $r_{1}$ & $\begin{array}{l}\infty \\
\infty \\
\\
\end{array}$ & $\begin{array}{l}\infty \\
\infty \\
\dot{p}\end{array}$ & $\begin{array}{l}\infty \\
\dddot{m} \\
\dddot{p}\end{array}$ & 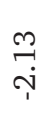 & $\begin{array}{l}\infty \\
\infty \\
\\
\end{array}$ & $\begin{array}{l}\stackrel{\leftrightarrow}{N} \\
\stackrel{\sim}{\sim}\end{array}$ & $\begin{array}{l}\infty \\
\text { nִ } \\
\stackrel{-}{r}\end{array}$ & $\begin{array}{l}\text { శ్ } \\
\text { } \\
1\end{array}$ & חִָ \\
\hline 됙 & $B$ & $\stackrel{2}{\Lambda}$ & $\bullet$ & $\wedge$ & $\begin{array}{l}\text { L } \\
\infty\end{array}$ & $\stackrel{0}{\rightarrow-1}$ & $\infty$ & $\begin{array}{l}\text { L } \\
\infty\end{array}$ & $\Lambda$ & $\begin{array}{l}\text { L? } \\
\infty\end{array}$ & น? & $\infty$ & $\begin{array}{l}\text { L } \\
\infty\end{array}$ & $a$ & เ? & $a$ & เ? & เก & เก & $\begin{array}{l}\text { L? } \\
\infty\end{array}$ & $\begin{array}{l}1 ? \\
\infty\end{array}$ \\
\hline \multirow[t]{2}{*}{ นึ } & 록 & 0 & $\hat{n}$ & กִ & $\begin{array}{l}\hat{\infty} \\
\dot{1}\end{array}$ & ᄂ? & $\begin{array}{l}10 \\
\infty\end{array}$ & ヘุ & $\underset{\infty}{\stackrel{10}{\aleph}}$ & $\stackrel{\infty}{\infty}$ & ָิ & $\Lambda$ & $\begin{array}{l}\tilde{b} \\
\dot{\theta}\end{array}$ & $\begin{array}{l}\stackrel{N}{7} \\
\stackrel{1}{*}\end{array}$ & 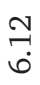 & $\begin{array}{l}\infty \\
0 \\
0\end{array}$ & 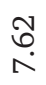 & $\stackrel{\stackrel{n}{N}}{\aleph}$ & $\underset{\infty}{\stackrel{N}{\sim}}$ & $\begin{array}{l}\hat{\infty} \\
\dot{1}\end{array}$ & ט \\
\hline & & $\overrightarrow{\mathrm{N}}$ & N & 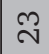 & $\stackrel{+}{\sim}$ & $\stackrel{\llcorner}{\sim}$ & $\stackrel{\bullet}{\sim}$ & $\widehat{\widehat{N}}$ & $\stackrel{\infty}{\sim}$ & ภे & ㅇ & $\vec{m}$ & ๗ె & $\stackrel{m}{m}$ & ले & $\stackrel{\text { ஸे }}{n}$ & లి & nิ & $\stackrel{\infty}{\infty}$ & શે & 우 \\
\hline
\end{tabular}




\begin{tabular}{|c|c|c|c|c|c|c|c|c|c|c|c|c|c|c|c|c|c|c|c|c|c|}
\hline $\begin{array}{l}\dot{0} \\
\text { 휴 } \\
\stackrel{0}{0}\end{array}$ & $\begin{array}{l}0 \\
0\end{array}$ & 교됴 & 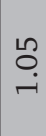 & $\stackrel{\digamma}{\check{r}}$ & $r$ & $\stackrel{\text { Ln }}{\mathrm{i}}$ & $\begin{array}{l}0 \\
0\end{array}$ & $\begin{array}{l}0 \\
\stackrel{1}{i}\end{array}$ & 0 & $\stackrel{0}{0}$ & $\stackrel{N}{0}$ & $\stackrel{\text { n̊ }}{\stackrel{n}{r}}$ & In & $\stackrel{+}{\circ}$ & ڤ2 & $r$ & $\begin{array}{l}10 \\
\text { 10 } \\
0\end{array}$ & $\stackrel{+}{\circ}$ & $\begin{array}{l}n \\
0 \\
0 \\
0\end{array}$ & $\stackrel{+}{\circ}$ & $\begin{array}{l}n \\
0 \\
0 \\
0\end{array}$ \\
\hline 뙤도 & $\infty$ & $\infty$ & $\infty$ & $\stackrel{n}{\Lambda}$ & 0 & ?ִ & $\stackrel{\text { 누 }}{\Lambda}$ & กุ & $\infty$ & $a$ & $a$ & $\infty$ & $\stackrel{n}{\Lambda}$ & $\stackrel{2}{n}$ & $\infty$ & ? & $a$ & $\Lambda$ & $\begin{array}{l}10 \\
\infty\end{array}$ & $a$ & $\infty$ \\
\hline ᄂ & $\stackrel{\nabla}{\Lambda}$ & $\stackrel{10}{\stackrel{1}{\circ}}$ & $\begin{array}{l}\stackrel{2}{\circ} \\
\circ\end{array}$ & $\underset{\infty}{\infty}$ & $\Lambda$ & $\begin{array}{l}\stackrel{2}{\alpha} \\
\infty\end{array}$ & ตे & o. & $\infty$ & $\stackrel{0}{a}$ & $\stackrel{\sim}{a}$ & $\stackrel{\text { n̊ }}{\text { å }}$ & 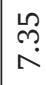 & $\stackrel{9}{1}$ & $\begin{array}{l}\stackrel{2}{\alpha} \\
\infty\end{array}$ & กุ & $\begin{array}{l}\text { นก } \\
\text { ஸุ }\end{array}$ & $\stackrel{+}{\sim}$ & $\begin{array}{l}\text { L } \\
\infty \\
\end{array}$ & $\stackrel{+}{\sigma}$ & $\stackrel{2}{\Omega}$ \\
\hline $\begin{array}{l}\dot{0} \\
\text { dें } \\
\dot{0} \\
\dot{0}\end{array}$ & 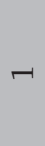 & 0 & $N$ & $N$ & - & 0 & ? & ${ }_{1}$ & ᄀ & $\checkmark$ & ㄱ & ㄱ & $\neg$ & ? & 0 & $\underset{1}{T}$ & $\neg$ & ? & 0 & $r_{1}$ & $\neg$ \\
\hline 秝诖 & $\Lambda$ & $\stackrel{0}{\circ}$ & $\infty$ & $\Lambda$ & 0 & 0 & $a$ & $\Lambda$ & $\infty$ & 10 & $\infty$ & $a$ & $\Lambda$ & $a$ & 0 & 윽 & $\infty$ & $\stackrel{\circ}{\circ}$ & $a$ & $\infty$ & 0 \\
\hline ᄂ & $\infty$ & $\stackrel{ }{\circ}$ & $\stackrel{0}{\circ}$ & $a$ & $\Lambda$ & 0 & 0 & 0 & $\Lambda$ & $a$ & $\Lambda$ & $\infty$ & $\infty$ & 0 & 0 & $\infty$ & $a$ & $\Lambda$ & $a$ & $\Lambda$ & $\Lambda$ \\
\hline 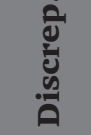 & 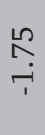 & ?ִ & \begin{tabular}{l}
$\stackrel{1}{N}$ \\
\multirow{1}{*}{}
\end{tabular} & 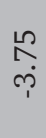 & ?? & $\begin{array}{l}n \\
\stackrel{1}{\Omega} \\
\stackrel{1}{0}\end{array}$ & 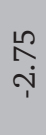 & 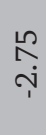 & ?ִ & $\begin{array}{l}\stackrel{1}{\curvearrowright} \\
\stackrel{1}{r}\end{array}$ & 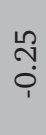 & $\nearrow_{1}$ & $\underset{1}{\Upsilon}$ & $\underset{1}{\Upsilon}$ & $\underset{T}{T}$ & $\digamma_{1}$ & $\stackrel{1}{0}$ & זִ & $\begin{array}{l}\stackrel{1}{N} \\
\text { ஸे }\end{array}$ & 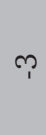 & ָூ \\
\hline 四 U & $\infty$ & $\infty$ & $a$ & $\stackrel{ }{\circ}$ & L & $\stackrel{0}{\rightarrow-1}$ & $a$ & $\stackrel{0}{-1}$ & $\infty$ & $\infty$ & $\infty$ & $\stackrel{0}{\rightarrow-1}$ & $\infty$ & $a$ & $a$ & $\stackrel{0}{\circ}$ & $\infty$ & $\Lambda$ & $\stackrel{0}{\circ}$ & $\stackrel{0}{-1}$ & $a$ \\
\hline u & ஸึ & $\stackrel{2}{\Lambda}$ & 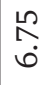 & 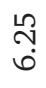 & ?ִ & $\stackrel{\llcorner}{\sim}$ & $\stackrel{\text { ஸn }}{\emptyset}$ & $\stackrel{\stackrel{2}{N}}{\Lambda}$ & กั & 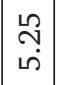 & $\stackrel{\llcorner}{\curvearrowright}$ & $a$ & 0 & $\Lambda$ & $\Lambda$ & $a$ & $\begin{array}{l}\stackrel{2}{\infty} \\
\infty\end{array}$ & $\begin{array}{l}\text { L } \\
\text { ம0 }\end{array}$ & 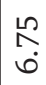 & $\Lambda$ & $\stackrel{n}{\stackrel{n}{\curvearrowright}}$ \\
\hline 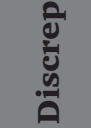 & $\begin{array}{l}\infty \\
\text { } \\
i \\
i\end{array}$ & $\begin{array}{l}\infty \\
\infty \\
\\
\end{array}$ & $\stackrel{\sim}{\stackrel{N}{\circ}}$ & ִָ & ?ִ & חִ זִ & 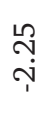 & $\begin{array}{l}\tilde{b} \\
\dot{p}\end{array}$ & ?ִ & 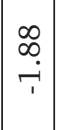 & - & ${ }_{1}$ & $\stackrel{m}{\stackrel{m}{+}}$ & $\stackrel{\stackrel{\nu}{n}}{\stackrel{p}{p}}$ & $\begin{array}{l}\infty \\
\infty \\
0 \\
0\end{array}$ & $\underset{T}{\top}$ & مִ & $\begin{array}{l}\stackrel{\sim}{N} \\
\stackrel{\sim}{i}\end{array}$ & $\begin{array}{l}\text { శ్ర } \\
\dot{p}\end{array}$ & $\stackrel{\Upsilon}{\top}$ & ঙ \\
\hline $\overrightarrow{0}$ & $\stackrel{2}{\Lambda}$ & $\stackrel{\circ}{ }$ & $\stackrel{2}{\Lambda}$ & $\infty$ & เ? & $a$ & ก & 1? & เ? & $\Lambda$ & $\Lambda$ & $\infty$ & เ? & $a$ & $\infty$ & $a$ & $\stackrel{ }{\circ}$ & $\stackrel{n}{1}$ & เด & $a$ & in \\
\hline 里 & 군 & $\stackrel{\sim}{\sim}$ & 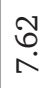 & 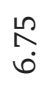 & 0 & $\stackrel{n}{\Lambda}$ & ஸึ & $\begin{array}{l}\widehat{\infty} \\
\infty \\
\dot{1}\end{array}$ & 0 & $\underset{\text { 무 }}{\stackrel{N}{7}}$ & $\infty$ & $\wedge$ & ஸे & $\stackrel{L}{\stackrel{n}{\Lambda}}$ & $\stackrel{\sim}{\stackrel{\sim}{\sim}}$ & $\Lambda$ & 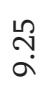 & $\begin{array}{l}\stackrel{n}{N} \\
\text { ம் }\end{array}$ & $\begin{array}{l}\widehat{\infty} \\
\infty \\
\dot{1}\end{array}$ & $\Lambda$ & ?ִ \\
\hline & F & $\stackrel{\mathfrak{T}}{\mathrm{T}}$ & $\stackrel{\mathscr{f}}{+}$ & ষ & 饮 & ơ & $\hat{\sigma}$ & $\stackrel{\infty}{+}$ & ga & 오 & 도 & กิ & กี & 亡ั & เก & เి & مि & 冓 & શે & 8 & $\bar{b}$ \\
\hline
\end{tabular}


Ana Tomović, Tamara Aralica, Katarina Rasulić: Mind the Gap!

\begin{tabular}{|c|c|c|c|c|c|c|c|c|c|c|c|c|c|c|c|c|c|c|c|c|c|c|c|}
\hline $\begin{array}{l}\text { वै } \\
\text { हैं } \\
\text { के }\end{array}$ & $\stackrel{+}{\circ}$ & مْ & $\stackrel{?}{0}$ & $\stackrel{n}{0}$ & $\ddot{\circ}$ & $\neg$ & $\stackrel{0}{0}$ & ஸ़ & $\hat{\circ}$ & ஸึ & $\begin{array}{l}20 \\
0 \\
0 \\
1\end{array}$ & $\stackrel{2}{0}$ & 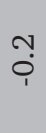 & $\begin{array}{l}+ \\
\dot{1}\end{array}$ & $\begin{array}{c}\text { N } \\
0 \\
0\end{array}$ & $\hat{0}$ & † & $\begin{array}{l}\text { L } \\
0 \\
0\end{array}$ & 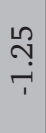 & 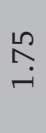 & $\stackrel{\text { ભn }}{\text { ๓n }}$ & 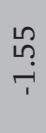 & $\begin{array}{l}\text { Ln } \\
\text { تُ }\end{array}$ \\
\hline 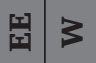 & $a$ & 0 & $\begin{array}{l}\text { ᄂ? } \\
\infty\end{array}$ & $\begin{array}{l}\stackrel{2}{\infty} \\
\infty\end{array}$ & $\infty$ & $a$ & $\Lambda$ & ᄂ? & $\infty$ & $\infty$ & $\Lambda$ & ?ִ & $\stackrel{n}{\Lambda}$ & $\infty$ & ? & $\infty$ & $a$ & $\infty$ & $\infty$ & ᄂ? & $\stackrel{?}{\Lambda}$ & เก & $\infty$ \\
\hline L & $\stackrel{\nabla}{\circ}$ & 농 & $\begin{array}{l}\infty \\
\infty\end{array}$ & $\begin{array}{l}\infty \\
\infty\end{array}$ & $\stackrel{-}{\infty}$ & $\stackrel{\circ}{ }$ & $\stackrel{\llcorner}{\Lambda}$ & 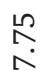 & $\widehat{\infty}$ & $\stackrel{\text { ํํ }}{\text { å }}$ & $\begin{array}{l}2 \\
\hat{0}\end{array}$ & $\Lambda$ & $\stackrel{?}{\sim}$ & $\stackrel{\bullet}{\sim}$ & $\begin{array}{l}n \\
a \\
a\end{array}$ & $\widehat{\infty}$ & $\infty$ & $\stackrel{2}{\Omega}$ & 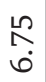 & $\stackrel{\text { ஸ̊ }}{a}$ & $\begin{array}{l}\infty \\
\infty \\
\infty\end{array}$ & 오 & $\begin{array}{l}\stackrel{\infty}{\infty} \\
\stackrel{0}{N}\end{array}$ \\
\hline $\begin{array}{l}\dot{0} \\
\text { ḋ } \\
\stackrel{0}{0} \\
\stackrel{0}{0}\end{array}$ & $\neg$ & - & 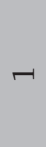 & 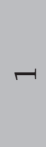 & ฯ & $\digamma_{1}$ & $\nearrow_{1}$ & $m$ & 0 & 0 & $r$ & $N$ & 0 & $m$ & - & $m$ & N & $m$ & $\nearrow_{1}$ & 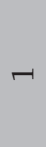 & ${ }_{1}$ & $m$ & N \\
\hline$\underset{⿶}{u}$ & $a$ & $\Lambda$ & $\infty$ & $\Lambda$ & $\infty$ & $a$ & $\Lambda$ & 0 & $a$ & $\Lambda$ & $\infty$ & ๑ & $\Lambda$ & $\Lambda$ & $\infty$ & L & $\Lambda$ & 6 & $\infty$ & 0 & $\Lambda$ & $\Lambda$ & $\infty$ \\
\hline U্ & 윽 & $\infty$ & $a$ & $\infty$ & $\bullet$ & $\infty$ & 0 & $a$ & $a$ & $\Lambda$ & $a$ & $\infty$ & $\Lambda$ & $\stackrel{ }{\circ}$ & $a$ & $\infty$ & $a$ & $a$ & $\Lambda$ & $\Lambda$ & 0 & $\stackrel{ }{\circ}$ & $\stackrel{\circ}{-1}$ \\
\hline 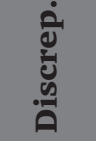 & 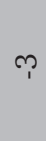 & $r_{1}$ & 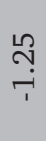 & 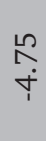 & זֶ & بִ & 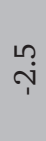 & 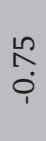 & 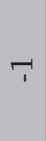 & $r_{1}$ & $\begin{array}{l}\stackrel{0}{\widehat{N}} \\
\stackrel{1}{r}\end{array}$ & $\begin{array}{l}\stackrel{2}{\text { N }} \\
\stackrel{+}{+}\end{array}$ & $\begin{array}{l}\stackrel{20}{\Uparrow} \\
\text { pr }\end{array}$ & $\begin{array}{l}\stackrel{2}{N} \\
\stackrel{+}{i}\end{array}$ & $\begin{array}{l}\stackrel{1}{\sim} \\
\underset{1}{1}\end{array}$ & 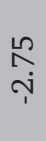 & $\underset{1}{T}$ & חִ & $\begin{array}{l}\stackrel{L}{\widehat{N}} \\
\stackrel{\gamma}{r}\end{array}$ & ְִ & $r_{1}$ & $\underset{1}{T}$ & بִ \\
\hline U & $a$ & $\Lambda$ & $\underset{\sim}{\stackrel{-}{1}}$ & $\stackrel{\circ}{\circ}$ & $a$ & $\stackrel{ }{\circ}$ & $\stackrel{ }{\rightarrow-1}$ & $a$ & $a$ & $\underset{\sim}{\circ}$ & $a$ & $\stackrel{0}{\circ}$ & $\underset{-}{-}$ & $\stackrel{ }{\circ}$ & $\stackrel{ }{-1}$ & $\infty$ & $a$ & $\Lambda$ & $\stackrel{ }{\circ}$ & $a$ & $\Lambda$ & $\infty$ & $\stackrel{0}{\circ}$ \\
\hline U & 0 & 0 & $\underset{\infty}{\stackrel{1}{\curvearrowright}}$ & $\begin{array}{l}\stackrel{1}{N} \\
\text { เִ }\end{array}$ & ᄂ? & เก & $\stackrel{n}{\Lambda}$ & ஸे & $\infty$ & $a$ & $\begin{array}{l}\stackrel{1}{0} \\
\qquad\end{array}$ & 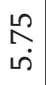 & 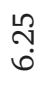 & 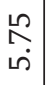 & 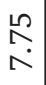 & 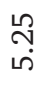 & $\Lambda$ & $\begin{array}{l}10 \\
\infty\end{array}$ & $\stackrel{\substack{N \\
N}}{ }$ & ก) & 6 & 0 & 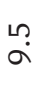 \\
\hline $\begin{array}{l}\text { वें } \\
\text { यूँ } \\
\stackrel{0}{a}\end{array}$ & $\begin{array}{l}\infty \\
\text { n } \\
\stackrel{r}{r}\end{array}$ & 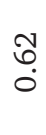 & חִ זִ & مִ ْْ & 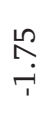 & $\begin{array}{l}\text { అִ } \\
\underset{r}{r}\end{array}$ & 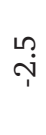 & $\begin{array}{l}\infty \\
\text { } \\
\text { } \\
\text { in }\end{array}$ & $\begin{array}{l}\text { L } \\
\text { Oे }\end{array}$ & $\begin{array}{l}\infty \\
\text { } \\
\text { } \\
\text { in }\end{array}$ & 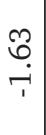 & חִ & $\begin{array}{l}\infty \\
\infty \\
\text { ஸे }\end{array}$ & $\begin{array}{l}m \\
\stackrel{m}{1} \\
\ddot{1}\end{array}$ & $\begin{array}{c}m \\
\underset{1}{\sim}\end{array}$ & 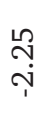 & $\begin{array}{l}\infty \\
\text { mp } \\
\text { p. }\end{array}$ & 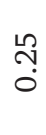 & \begin{tabular}{l}
$\infty$ \\
$\infty$ \\
\multirow{1}{1}{}
\end{tabular} & 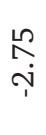 & זָْ & 官 & $\begin{array}{l}\stackrel{2}{\curvearrowright} \\
\text { pे }\end{array}$ \\
\hline B & $\stackrel{\circ}{ }$ & $\begin{array}{l}\text { L } \\
\text { เก }\end{array}$ & เก & a & $\infty$ & $\underset{-1}{0}$ & $\begin{array}{l}\text { L? } \\
\infty\end{array}$ & เก & $a$ & เก & $\curvearrowright$ & $\Lambda$ & $\infty$ & a & $\stackrel{0}{\rightarrow}$ & เก & $\begin{array}{l}\text { L } \\
\infty\end{array}$ & ๒? & น? & $a$ & $\begin{array}{l}\text { L? } \\
\infty\end{array}$ & $\stackrel{0}{\rightarrow}$ & เก \\
\hline 是 & $\begin{array}{l}\text { రె } \\
\infty\end{array}$ & 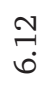 & $\infty$ & $\stackrel{\text { กִ }}{\Lambda}$ & 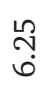 & $\begin{array}{c}\hat{\infty} \\
\infty\end{array}$ & ט & 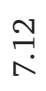 & 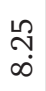 & $\stackrel{\sim}{\sim}$ & $\begin{array}{l}\hat{m} \\
\text { ம் }\end{array}$ & טִ & $\begin{array}{l}\text { ㄱ. } \\
\text { in }\end{array}$ & $\begin{array}{l}\hat{\infty} \\
\dot{\omega}\end{array}$ & $\begin{array}{l}\widehat{\infty} \\
\stackrel{\Lambda}{\alpha}\end{array}$ & $\begin{array}{l}\stackrel{2}{N} \\
N\end{array}$ & $\begin{array}{l}\stackrel{7}{7} \\
\stackrel{1}{*}\end{array}$ & 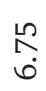 & $\begin{array}{l}\text { ஸै } \\
\text { ம}\end{array}$ & $\begin{array}{l}\stackrel{n}{n} \\
\text { }\end{array}$ & $\Lambda$ & חֶֶ & $\underset{\stackrel{R}{\curvearrowright}}{\stackrel{10}{\circ}}$ \\
\hline & ชื & ஜூ & రా & เூ & $\bullet$ & $\hat{\vartheta}$ & $\mathscr{b}$ & જิ & $\stackrel{P}{R}$ & $\vec{\Lambda}$ & $\mathfrak{N}$ & $\Re$ & $\underset{\sim}{\mathbb{N}}$ & $\stackrel{L}{\aleph}$ & $\stackrel{0}{\sim}$ & $\hat{\wedge}$ & $\stackrel{\infty}{\wedge}$ & 2 & ○ & $\vec{\infty}$ & $\infty$ & $\mathscr{\infty}_{\infty}$ & চ \\
\hline
\end{tabular}




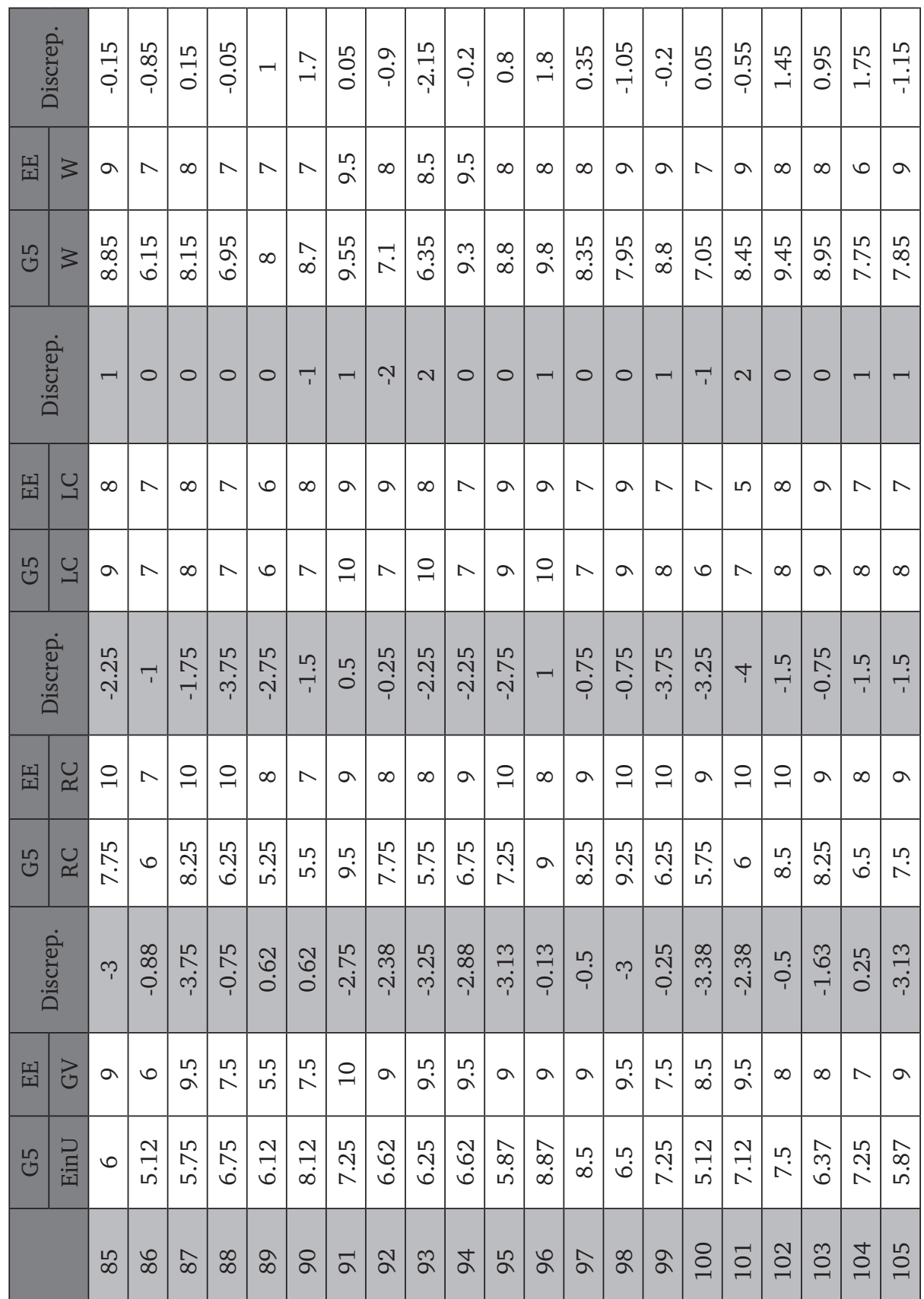




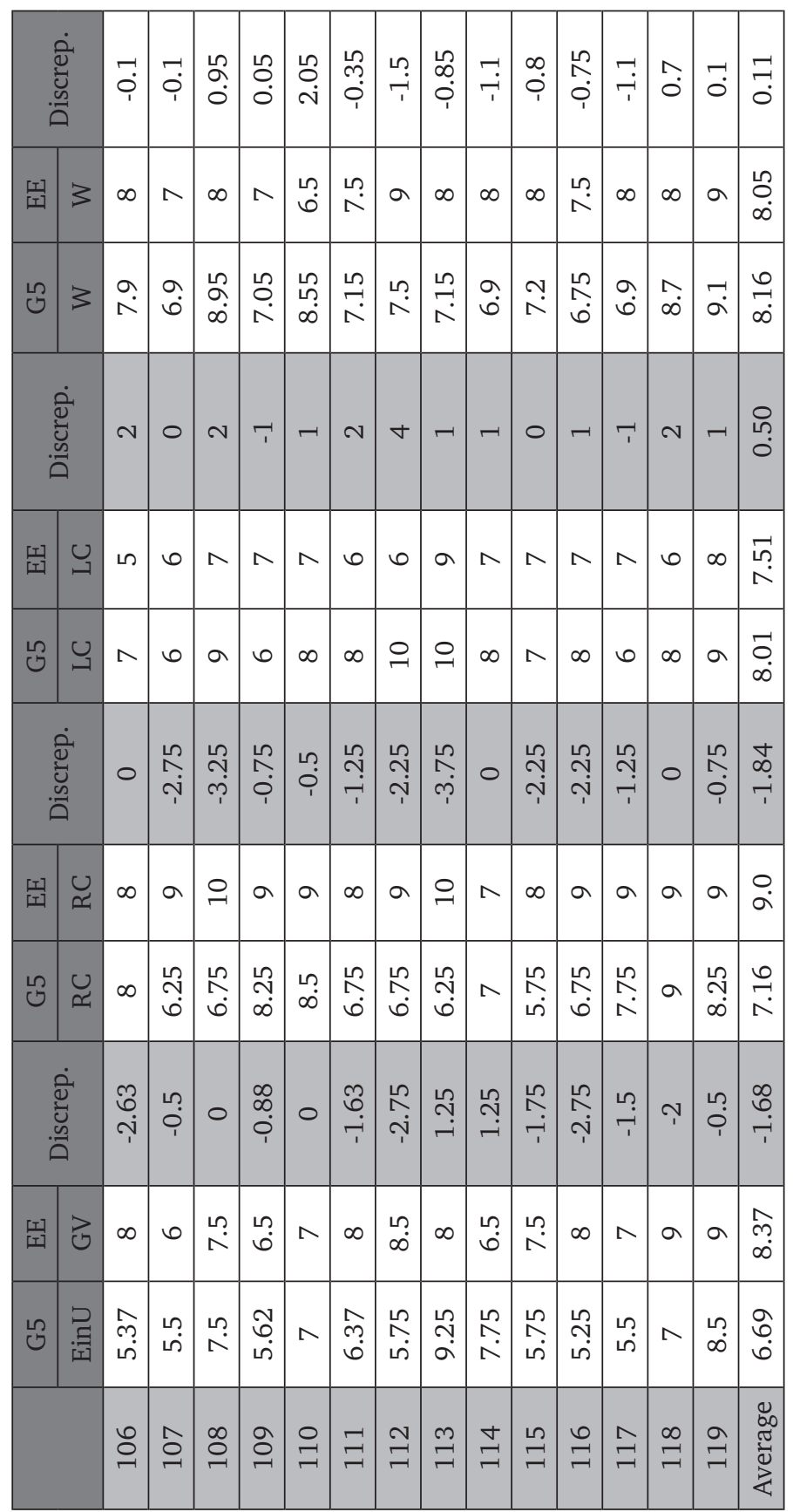




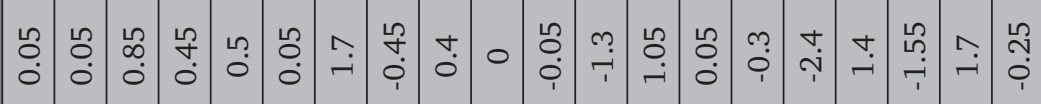

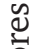

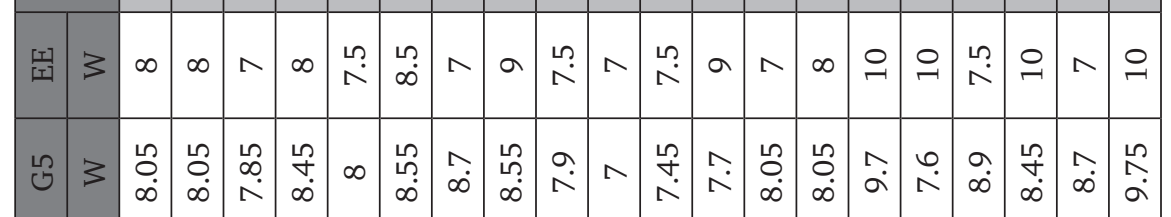

莖
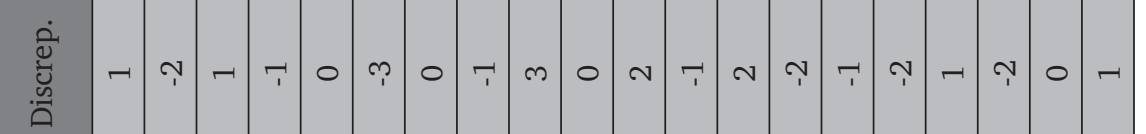

.

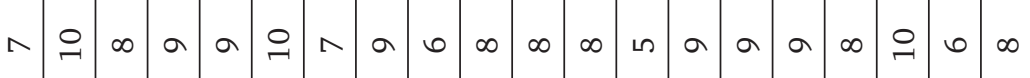

की

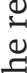

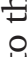

范

$\mathscr{e}$

ठั้

్ㅗㅈ

苂

눈

늉

$\stackrel{2}{=}$

E

$\frac{0}{\frac{0}{\pi}}$

ᄂ

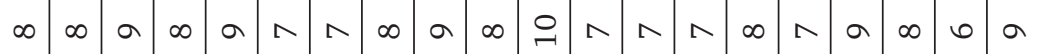

in

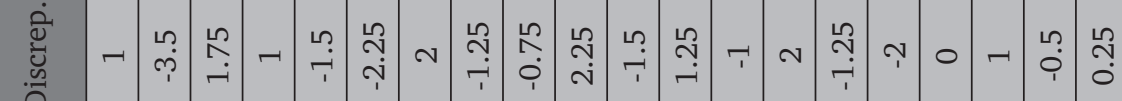

되

$\infty \quad a \wedge \infty$

○

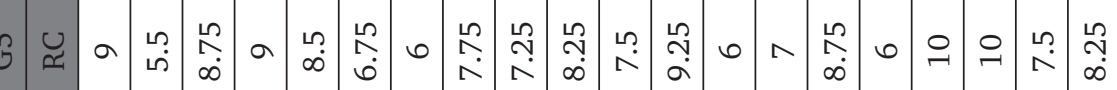

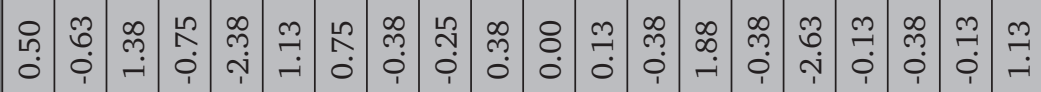

$\stackrel{m}{a}$

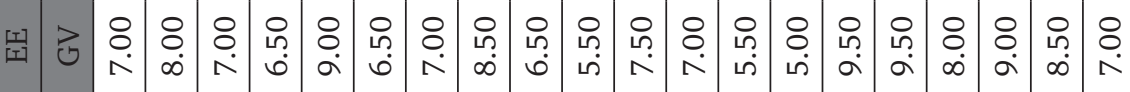

荧

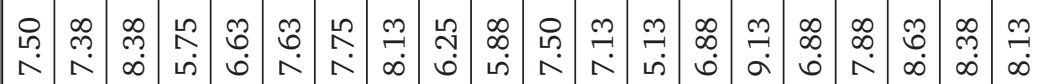

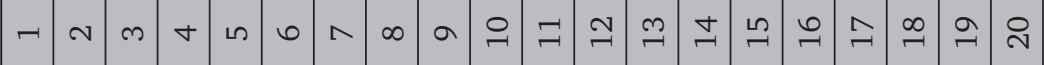




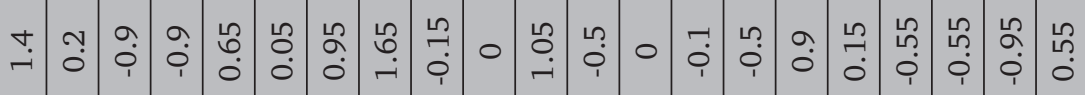

됟 3

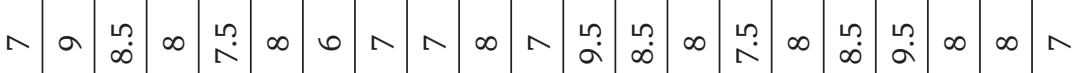

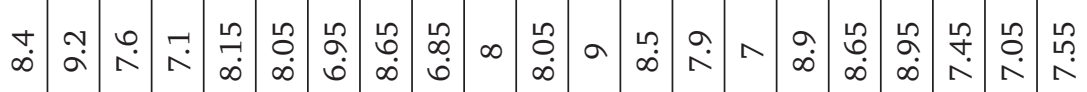

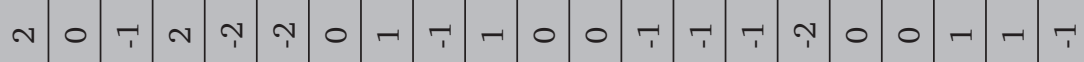

똟

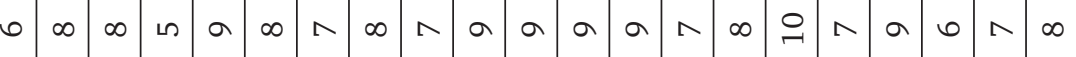

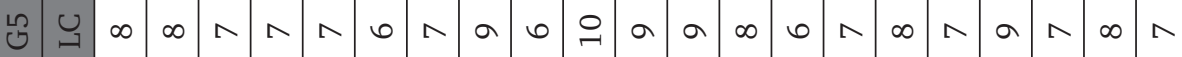

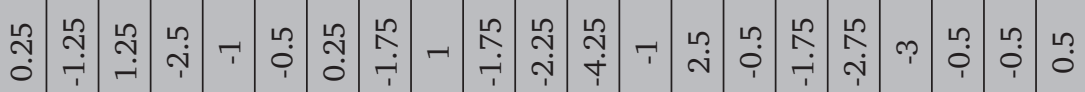

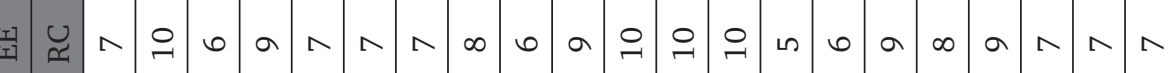

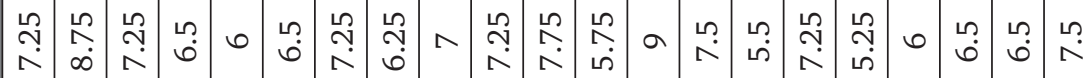

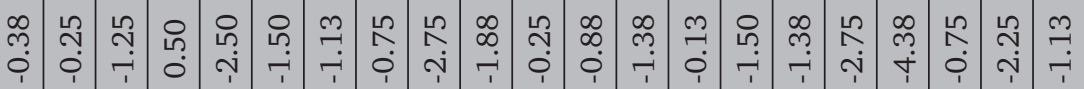

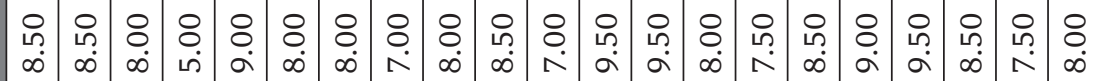

$m$ 舟

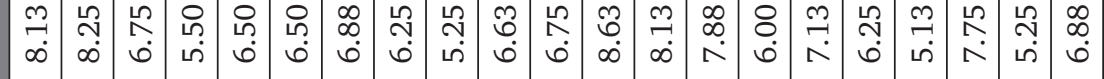

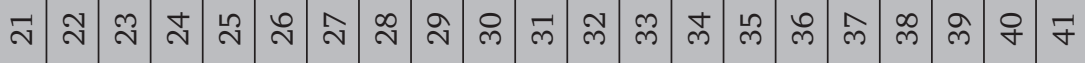




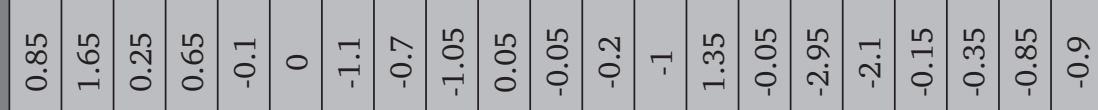

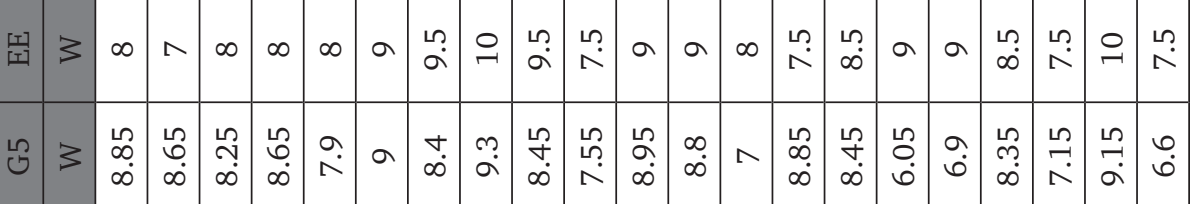

वें

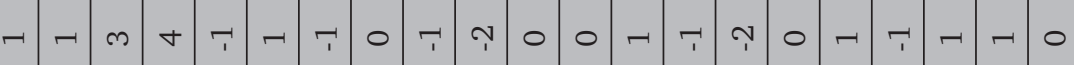

$\ddot{\Delta}$

넏

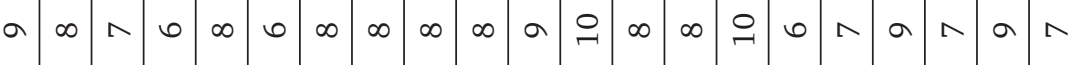

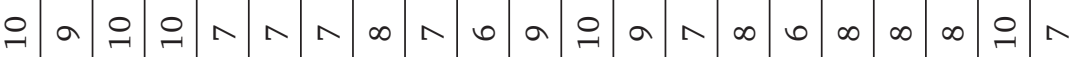

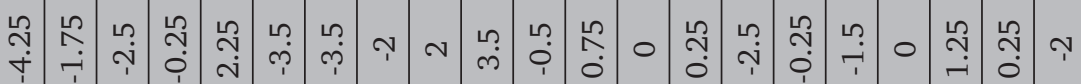

뙫

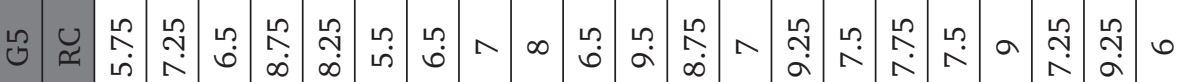

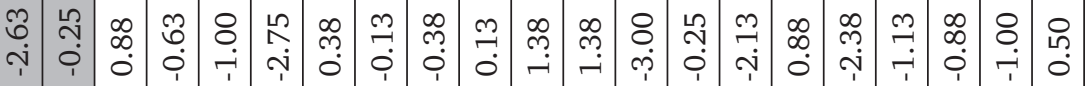

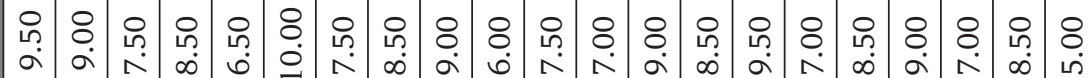

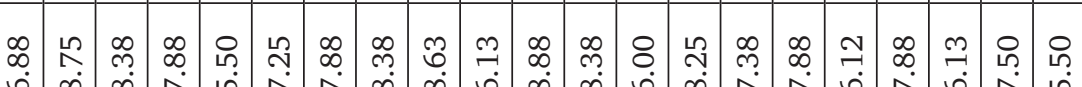

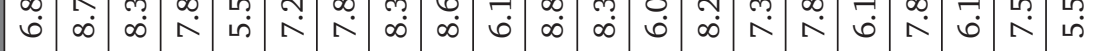

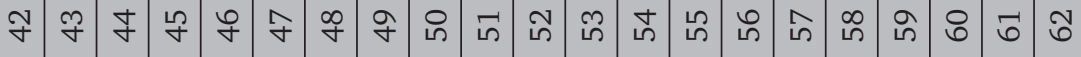




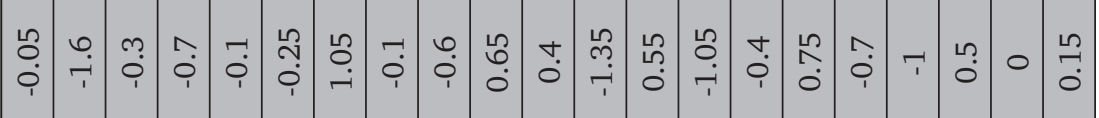

\begin{tabular}{|c|c|c|c|c|c|c|c|c|c|c|c|c|c|c|c|c|c|c|c|c|}
\hline 3 & مִ & $a$ & $\stackrel{\circ}{-}$ & مִ & $\infty$ & $\infty$ & ก? & $a$ & $\infty$ & $\Lambda$ & $\infty$ & $a$ & $\infty$ & $\Lambda$ & $a$ & $a$ & $\infty$ & ᄂ? & $\stackrel{n}{\Lambda}$ & $a$ \\
\hline 3 & $\stackrel{\text { ֻ }}{\stackrel{\sim}{\sim}}$ & $\stackrel{\nabla}{\sim}$ & $\hat{a}$ & $\stackrel{\infty}{0}$ & $\stackrel{9}{\Omega}$ & 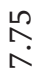 & $\begin{array}{l}\text { 足 } \\
\infty \\
\infty\end{array}$ & $\begin{array}{l}a \\
\infty\end{array}$ & $\stackrel{⿱}{\Delta}$ & $\begin{array}{l}\mathscr{0} \\
\stackrel{\sim}{0}\end{array}$ & $\underset{\infty}{+}$ & مِّ & $\begin{array}{l}\text { 足 } \\
\infty \\
\infty\end{array}$ & $\begin{array}{l}\text { مे } \\
\dot{1}\end{array}$ & $\begin{array}{l}\varphi \\
\infty\end{array}$ & 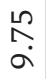 & $\stackrel{m}{\sim}$ & صִ & $\infty$ & $a$ \\
\hline
\end{tabular}




\begin{tabular}{|c|c|c|c|c|c|c|c|c|c|c|c|c|c|c|c|c|c|c|}
\hline \multicolumn{2}{|c|}{$\begin{array}{l}\dot{0} \\
\dot{u} \\
\ddot{0} \\
\ddot{0}\end{array}$} & $\begin{array}{l}\text { L } \\
\text { Oீ }\end{array}$ & $\ddot{~}$ & $\stackrel{N}{0}$ & $\begin{array}{l}\text { L } \\
\text { تُ } \\
\end{array}$ & $\begin{array}{l}\text { L } \\
\stackrel{2}{\circ}\end{array}$ & $\stackrel{\text { L? }}{0}$ & $\begin{array}{l}\text { 우 } \\
\text { بி }\end{array}$ & ${ }_{1}$ & $\begin{array}{l}\text { Ln } \\
\text { 무 }\end{array}$ & $\stackrel{\text { Ln }}{+}$ & & $\begin{array}{l}\text { مू } \\
\text { ণิ }\end{array}$ & $\begin{array}{l}\text { மூ } \\
\stackrel{0}{0}\end{array}$ & $\begin{array}{l}\text { ஸे } \\
\text { Ọ }\end{array}$ & $\stackrel{+}{\circ}$ & $\begin{array}{l}\text { In } \\
\stackrel{0}{0}\end{array}$ & $\begin{array}{l}m \\
\stackrel{m}{0} \\
\stackrel{1}{0}\end{array}$ \\
\hline 效 & 3 & $a$ & $\stackrel{n}{\Lambda}$ & $\infty$ & $\infty$ & ? & $\stackrel{n}{\Lambda}$ & ᄂ? & $a$ & เก & $\Lambda$ & $a$ & เก & $a$ & $\infty$ & $\stackrel{ }{\circ}$ & $a$ & $\underset{\infty}{\stackrel{+}{\sim}}$ \\
\hline 으 & 3 & 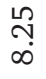 & $\stackrel{\nabla}{\sim}$ & $\stackrel{\infty}{\sim}$ & $\begin{array}{l}\stackrel{0}{\infty} \\
\stackrel{0}{\Lambda}\end{array}$ & $\begin{array}{l}\text { ڤn } \\
\infty\end{array}$ & $\infty$ & 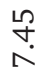 & $\infty$ & $\begin{array}{l}\stackrel{\text { n̊ }}{\text { å }}\end{array}$ & 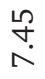 & $\begin{array}{l}\stackrel{\llcorner}{\infty} \\
\stackrel{\infty}{\Lambda}\end{array}$ & 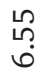 & $\begin{array}{l}\text { பூ } \\
\stackrel{a}{ }\end{array}$ & $\begin{array}{l}\qquad 0 \\
\end{array}$ & $\stackrel{0}{\sigma}$ & $\begin{array}{l}10 \\
\\
\infty\end{array}$ & $\underset{\sim}{\stackrel{\sim}{*}}$ \\
\hline \multicolumn{2}{|c|}{ 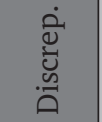 } & 0 & 0 & 0 & 0 & 0 & 0 & $N$ & $m$ & & $\digamma_{1}$ & $\neg$ & $\digamma_{1}$ & 0 & 0 & 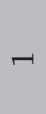 & $\Upsilon$ & $\begin{array}{l}\text { ¿ } \\
\text {. }\end{array}$ \\
\hline 뇓ㄱ & U্త & $\infty$ & $\Lambda$ & $\Lambda$ & $\Lambda$ & 윽 & $\infty$ & L & $\Lambda$ & $\infty$ & $\Lambda$ & $\infty$ & $a$ & $a$ & $\infty$ & $a$ & $\infty$ & @) \\
\hline 농 & U. & $\infty$ & $\Lambda$ & $\Lambda$ & $\Lambda$ & $\stackrel{\circ}{\circ}$ & $\infty$ & $\Lambda$ & 우 & $\bullet$ & 0 & $a$ & $\infty$ & $a$ & $\infty$ & $\stackrel{ }{-}$ & ט & ळ. \\
\hline \multicolumn{2}{|c|}{$\begin{array}{l}\dot{0} \\
\stackrel{0}{0} \\
\ddot{0}\end{array}$} & $\begin{array}{l}\text { กิ } \\
\text { ஸे }\end{array}$ & 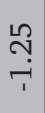 & חִ & $\stackrel{\text { ㄴ? }}{7}$ & $r_{1}$ & 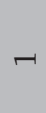 & 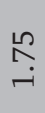 & ?ִ & $r_{1}$ & In & $\stackrel{\stackrel{\sim}{\sim}}{\stackrel{\sim}{v}}$ & 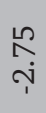 & חִ & 0 & $\begin{array}{l}\stackrel{1}{0} \\
0 \\
0\end{array}$ & $\neg$ & $\begin{array}{l}\text { กิ } \\
\text { ஸि } \\
\text { î }\end{array}$ \\
\hline 덛 & U્વ & $\stackrel{0}{\rightarrow-1}$ & $\Lambda$ & $\infty$ & $a$ & $a$ & $\Lambda$ & L & $\infty$ & $\stackrel{ }{\circ}$ & $a$ & 6 & $\stackrel{ }{\circ}$ & 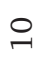 & $\infty$ & $\stackrel{ }{\circ}$ & م & $\begin{array}{l}\text { oे } \\
\infty\end{array}$ \\
\hline 농 & $\underset{\simeq}{U}$ & $\stackrel{n}{\Lambda}$ & 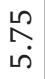 & טִ & ᄂ? & $\infty$ & $\infty$ & $\begin{array}{l}\stackrel{2}{\Im} \\
\sigma\end{array}$ & L & $a$ & חִ & $\underset{\infty}{\stackrel{\infty}{\curvearrowright}}$ & 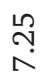 & $\begin{array}{l}\text { L } \\
\infty\end{array}$ & $\infty$ & $\begin{array}{l}\stackrel{n}{\curvearrowright} \\
a\end{array}$ & ט & 두 \\
\hline \multicolumn{2}{|c|}{$\begin{array}{l}\text { 己ें } \\
\stackrel{\mathscr{D}}{0}\end{array}$} & $\begin{array}{l}\text { అூ } \\
\ddot{p}\end{array}$ & $\begin{array}{l}\text { N̦ } \\
\text { }\end{array}$ & $\begin{array}{l}\infty \\
\text { nִ } \\
\end{array}$ & $\begin{array}{l}\infty \\
\infty \\
\underset{1}{1}\end{array}$ & 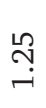 & 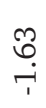 & $\begin{array}{l}\infty \\
\text { mp } \\
\stackrel{1}{0}\end{array}$ & $\begin{array}{l}\infty \\
\text { mִ } \\
\stackrel{1}{1}\end{array}$ & $\begin{array}{l}\infty \\
\infty \\
\dot{0} \\
\dot{1}\end{array}$ & $\begin{array}{l}\text { ○ } \\
\text { ○. }\end{array}$ & $\begin{array}{l}\infty \\
\infty \\
0 \\
0\end{array}$ & $\begin{array}{l}0 \\
\text { ஸे } \\
\text { ஸे }\end{array}$ & $\begin{array}{l}\text { అூ } \\
\underset{+}{+}\end{array}$ & $\begin{array}{l}\infty \\
\text { } \\
\stackrel{1}{1}\end{array}$ & $\begin{array}{l}\infty \\
\text { m. } \\
0\end{array}$ & 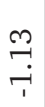 & $\begin{array}{l}\stackrel{n}{ح} \\
\stackrel{0}{1}\end{array}$ \\
\hline 뙫 & $\vec{ن}$ & $\begin{array}{l}\circ \\
\text { ○े }\end{array}$ & $\begin{array}{l}\text { 우 } \\
\text { }\end{array}$ & $\begin{array}{l}\bigcirc \\
\infty \\
\infty\end{array}$ & $\begin{array}{l}0 \\
\infty \\
\infty\end{array}$ & 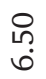 & $\begin{array}{l}0 \\
\text { గn } \\
\infty\end{array}$ & $\stackrel{\circ}{\circ}$ & $\begin{array}{l}\text { 우 } \\
\text { مْ }\end{array}$ & $\begin{array}{l}\text { 우 } \\
\text { å }\end{array}$ & $\begin{array}{l}\stackrel{8}{\infty} \\
\infty\end{array}$ & $\begin{array}{l}\text { 유 } \\
\infty \\
\infty\end{array}$ & $\begin{array}{l}\text { 우 } \\
\text { مْ }\end{array}$ & $\begin{array}{l}\text { 우 } \\
\text { å }\end{array}$ & 우 & $\begin{array}{l}8 \\
\text { ○े }\end{array}$ & $\begin{array}{l}\circ \\
\infty \\
\infty\end{array}$ & $\stackrel{\curvearrowright}{\curvearrowright}$ \\
\hline 노 & ? & $\begin{array}{l}\infty \\
\text { m. } \\
\text { in }\end{array}$ & $\begin{array}{l}\text { ヘึ } \\
\text { }\end{array}$ & $\begin{array}{l}\text { అִ } \\
\dot{0}\end{array}$ & $\begin{array}{l}\text { ఠర } \\
\text { ம் }\end{array}$ & 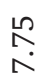 & $\begin{array}{l}\infty \\
\infty \\
0\end{array}$ & 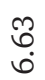 & $\stackrel{m}{a}$ & $\begin{array}{l}\approx \\
\varnothing \\
\infty\end{array}$ & $\stackrel{8}{\circ}$ & થి & $\begin{array}{l}8 \\
0 \\
0\end{array}$ & $\begin{array}{l}\infty \\
\infty \\
\end{array}$ & $\begin{array}{l}m \\
\stackrel{7}{H}\end{array}$ & $\begin{array}{l}\infty \\
\text { } \\
a\end{array}$ & $\begin{array}{l}\infty \\
\infty \\
0 \\
0\end{array}$ & 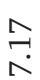 \\
\hline & & চ & $\stackrel{\infty}{\infty}$ & $\infty$ & $\infty$ & $\infty$ & ఎ & ৪ & ప̄ & ๙ & ๙ & ন & 느 & ฉั & $\hat{\sigma}$ & $\mathscr{2}$ & ลे & 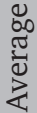 \\
\hline
\end{tabular}

